Завдання 4. Виправити помилки, пов'язані з явищем міжмовної інтерференції.

1. Зимові канікули тривали одну неділю. 2. На контрольній роботі необхідно було доказати теорему. 3. Ї̈̈ заставляли працювати без вихідних. 4. За жорстоке ставлення до власних дітей Василя Петренка суд лишив батьківських прав. 5. Наглий юнак образив літню жінку. 6. Студент не встиг розв'язати задачу, оскільки йому постійно мішали одногрупники. 7. На спортивних змаганнях ми боліли за команду нашого університету. 8. На екзамені Олег одержав низьку оцінку, тому що спутав формули.

Отже, застосування в навчальному процесі окресленої системи вправ сприяє грунтовному засвоєнню базових лексичних понять та вдосконаленню комунікативних умінь i навичок користуватися словом у сфері професійного спілкування.

\title{
Література
}

1. Мацюк 3. О. Українська мова професійного спілкування : навч. посіб./ 3. О. Мацюк, Н. І. Станкевич. - К. : Каравела, 2005. - 352 с. 2. Методика навчання української мови в середніх освітніх закладах / [Пентилюк М. І., Караман С. О., Караман О. В. та ін.] ; за ред. М. І. Пентилюк. - К. : Ленвіт, 2005. - 400 с. 3. Шевчук С. В. Українська мова за професійним спрямуванням : підручник / С. В. Шевчук, І. В. Клименко. - К. : Алерта, 2013. - 696 с.

УДК 378.147

Леся Потапкіна

\section{ШЛЯХИ РОЗВИТКУ В МАЙБУТНІХ ЕКОНОМІСТІВ УПРАВЛІНСЬКИХ ЯКОСТЕЙ І НАВИЧОК РОБОТИ В КОМАНДІ}

Потапкіна Л. В. Шляхи розвитку в майбутніх економістів управлінських якостей і навичок роботи в команді.

У статті виокремлено найважливіші здібності та якості, якими повинні володіти сучасні фахівці з менеджменту, визначено зачади досягнень менеджерів, економістів, подано методичні настанови, необхідні для ділової активності вдосконалення професійних здібностей, надано поради задля досягнення успіху на початковому етапі, наведено приклади використання в навчальному процесі ділових, імітаційних, інтелектуальних ігор та тренінгів, здійснили оцінку компетенцій.

Ключові слова: досягнення, ділова активність, професійні здібності, компетентність, тренінг.

Потапкина Л. В. Пути развития у будущих экономистов управленческих качеств и навыков работы в команде.

В статье выделены важнейшие способности и качества, которыми должны владеть современные специалисты по менеджменту, определены основы достижений менеджеров, экономистов, представлены методические установки, необходимые для деловой активности совершенствования профессиональных способностей, предоставлено советы для достижения успеха, приведены примеры использования в учебном процессе деловых, имитационных, интеллектуальных игр и тренингов, осуществили оценку компетенций.

Ключевые слова: достижение, деловая активность, профессиональные способности, компетентность, тренинг. 
Potapkina L. V. Ways of development of future economists managerial qualities and teamwork skills.

In this article, we have identified the most important skills and qualities, which must possess modern management specialists, determined based on what their best, managers, economists, provided methodological installation, which required for business improvement professional abilities, tried to provide tips for success in the beginning of the new case examples of use in teaching business, simulation, intellectual games and trainings carried out an assessment of competencies outlined.

Key words: achievement, business activities, professional ability, competence, training.

Важливий складник успіху корпорації- характер спілкування 3 людьми: повага до особистості (офіційно визнано визнання індивідуальності), єдиний статус усіх працівників, відбір фахівців найвищого класу, делегування відповідальності на найнижчі рівні.

О. Гроссман, відомий німецький економіст, розробив рекомендації задля досягнення успіху у книзі «В успіху є метод». Він уважає, що більшість менеджерів, які тільки починають працювати, та підприємців могли б досягти значно більших успіхів у своїй діяльності, якщо б діяли більш планомірно й цілеспрямовано. Більше того, своїм першочерговим завданням кожен підприємець має вважати конкурентне визначення завдань, що стоять перед ним. За оцінкою О. Гроссмана, лише три відсотки німецьких підприємств мають перед собою розумні, сформовані на папері завдання, і менше одного відсотка-ретельно відпрацьовану стратегію дій на конкретний відрізок часу.

Питаннями формування конкурентноздатності особистості займались такі науковці як: А. Ангеловський, Д. Котикова, Ф. Туктаров, В. Шаповалов; дослідження питань психології ровитку конкурентноздатної особистості М. Мітіна, а також В. Моляко (Творча конструктологія), А. Огнев (Організаційне консультування у стилі коучинг), А. Перцев (Коучинг: успіх після успіху), П. Тербин (Стратегічні ігри).

Основною проблемою, що залишається нерозв'язаною, є проблема підготовки конкурентоздатних випускників. Проте підходи й засоби організації навчальновиховного процесу ВНЗ, що сприяли б формуванню конкурентоспроможності студентів, недостатньо розроблені.

Mema cmammi - виокремити найважливіші здібності та якості, якими повинні володіти сучасні фахівці з менеджменту, визначити засади досягнень менеджерів, економістів, надати методичні настанови, необхідні для ділової активності вдосконалення професійних здібностей, надати поради для досягнення успіху на початку нової справи.

Майбутніх економістів навчаємо, що ретельне відпрацювання завдань і роботи підприємства - це ще далеко не все, що вимагається в сучасному менеджменті. Чинником номер один будь-якого успіху $є$ особистість самого підприємця чи менеджера, який має володіти низкою особистісних якостей і постійно займатися їх розвитком і вдосконаленням. Найвищі досягнення базуються виключно на вищому професіоналізмі, щоденному тренінгу та підвищенні рівня своїх здібностей, у тому числі й фізичної підготовки, тому що більше 80 \% підприємців можуть розвинути успіх своєї фірми за рахунок більш інтенсивної мобілізації сил і здібностей.

У центрі ділової активності вдосконалення професійних здібностей мають бути три методичні настанови: 
1. Розроблення конкретної мети й стратегії для ï досягнення на основі глибокого аналізу загального становища справ.

2. Поєднання головної мети 3 планами іiі досягнення на конкретних відрізках розв'язання поставленого перед собою завдання.

3. Забезпечення реалізації поставлених завдань чітким плануванням часу, потрібного для їх досягнення.

Слід звертати увагу студентів на ще один аспект щодо шляхів досягнення успіху: не забувати за лихоманкою ділових буднів про особисте життя, оскільки ділове й особисте життя менеджера взаємопов'язані та впливають одне на одного. Тільки монолітна життєва позиція може надати людині повне задоволення від життя, відчуття щастя. При цьому слід не забувати про здоров'я, оскільки саме воно $\epsilon$ важливим чинником успіху чи неуспіху в житті і роботі.

Слід учити майбутніх економістів, що менеджер високого класу відрізняється від просто кваліфікованого менеджера глибоко осмисленим і цілеспрямованим використанням часу. У того, хто володіє методами економії часу, значно підвищується ефективність трудових затрат. Однак не потрібно при цьому забувати про головну мету руху. Тому, хто прямує хибним напрямом, не допоможе економія часу.

3 точки зору аналізу менеджменту, головне - визначити правильні завдання й відпрацювати відповідну стратегію їх досягнення. В цьому полягає половина успіху. Чіткість завдань - головний чинник успіху. Для досягнення істинних успіхів потрібно повністю володіти ситуацією й докладати багато зусиль. Тому кожен менеджер має, насамперед, поставити собі запитання: які цілі він прагне досягнути в найближчі 5 років, які здібності йому потрібно розвивати в собі для досягнення цих честолюбивих завдань. При цьому кожен має ретельно продумати й уявити собі, які першочергові чинники можуть у тій чи іншій ситуації забезпечити йому особистий успіх. При цьому потрібно дотримуватися принципу - максимальний успіх за умови розумної мобілізації енергії та часу.

Кожен, хто хоче зробити успішну кар'єру, має тверезо й об'єктивно оцінити свої сили і здібності, визначити, що йому потрібно для самовдосконалення й розвитку, знайти свою мету і шляхи іiі досягнення. Особливо успіх необхідний на початку нової справи.

Досліджуючи політичні, соціальні, економічні та психологічні сили, які діють у різних країнах, і вивчаючи вплив цих сил на тих, хто займає управлінські посади, можна зробити корисні узагальнення про мінливість змісту роботи керівника. Ці узагальнення дозволяють передбачити ті здібності та вміння, які необхідні менеджеру нині і в майбутньому.

Проведені разом зі студентами дослідження надали змогу виокремити такі найважливіші якості менеджера, що впливають на управлінську діяльність: здатність ефективно управляти собою та своїм часом; здатність уточнити свої особисті цінності; визначення мети роботи, що виконується і власних цілей; постійне зростання й розвиток; здатність швидко й ефективно розв'язувати проблеми; винахідливість і здатність гнучко реагувати на зміни ситуації; вплив на оточуючих, не застосовуючи прямих наказів; використання нових сучасних управлінських прийомів; уміле використання людських ресурсів; вміння допомогти іншим у швидкому вивченні нових методів і оволодіння практичними навичками роботи; вміння створювати й удосконалювати групи, які здатні швидко ставати винахідливими й результативними в роботі. Це узагальнені здібності та якості, якими має володіти менеджер. Якщо детально розглядати це питання, то якості й 
риси керівника, яких досягає успіху, можна поділити на психологічні, інтелектуальні, професійні та соціальні. Рекомендовано аналізувати їх разом зі студентами.

Психологічні якості: прагнення бути лідером, здатність до керівництва; сильні вольові якості; готовність до розумного ризику; прагнення успіху; честолюбство; здатність до домінування в екстремальних умовах; самодостатність особистості; комбінаторно-прогностичний тип мислення (варіативність, темп, гнучкість, інтуїтивність, логічність, прогностичність); стійкість проти стресу; адаптивність, швидка пристосовуваність до нових умов.

Інтелектуальні якості: прагнення до постійного самовдосконалення; схильність до сприйняття нових ідей і досягнень; здатність відрізнити їх від ілюзорних; панорамність мислення (системність, широта, комплексність) і професійна предметність (знання деталей i тонкощів управління); мистецтво швидко опрацьовувати; ранжувати інформацію і на цій основі приймати рішення; здатність до самоаналізу; вміння розуміти, приймати і використовувати з користю для справи думки, протилежні власній; психологічна освіта.

Професійні якості: вміння ефективно використовувати кращі досягнення науково-технічного прогресу; глибокі знання особливостей функціонування ринкової економіки; схильність і здатність віднаходити резерви людського чинника в підприємництві; вміння заохочувати персонал за якісну роботу і справедливо критикувати; мистецтво приймати нестандартні управлінські рішення - здатність знаходити проблеми й розв'язання в тих умовах, коли альтернативні варіанти дій; інформація і цілі нечіткі або сумнівні; уміння ефективно й раціонально розподіляти завдання й виокремлювати на них оптимальний час; діловитість, постійний вияв ініціативи, підприємливість.

Соціальні риси: уміння враховувати соціальні наслідки прийнятих рішень; схильність керуватися принципами соціальної справедливості; уміння встановлювати й підтримувати систему стосунків 3 рівними собі людьми; тактовність і ввічливість, переважання демократичності у стосунках 3 людьми; уміння брати на себе відповідальність; беззастережне виконання правил, прийняті організацією; уміння заохочувати персонал до відвертості і групових дискусій.

Важливим моментом для керівника в управлінський діяльності $\epsilon$ те, щоб він у своїй фірмі був лідером. У лідера визначають п'ять характеристик: бізнесосвіченість; концептуальні здібності (творчий, винахідливий інтелект); попередній досвід; якість судження (прийняття швидких і правильних рішень за недостатньої інформації); вміння працювати з людьми (здатність захоплювати людей, повести за собою і дати їм розкритися; мужність підібрати людей, які висловлюють за потреби власну, нехай навіть протилежну думку).

Разом зі студентами доцільно робити висновок, що головним покликанням лідерів у подальші роки буде вивільнення інтелектуальної енергії своїх співробітників. Лідери повинні створити у своїх організаціях таку атмосферу, щоб люди пропонували якомога більше ідей, інновацій, цікавих теорій.

Успіх у діяльності менеджера невіддільний від процвітання фірми в цілому, i, навпаки, секрети успіху містяться в системі принципів, які складаються у процесі функціонування фірми. Наводимо приклад фірми IBM, якій допомагають перемагати такі принципи: сильне переконання, що зумовлює встановлення певної мети в межах цього підходу; етичні цінності, що сприймаються працівниками; політика повної зайнятості (довічний найм); різноманітність у роботі; особисте стимулювання; розвиток неспеціалізованої кар'єри; особиста (на основі консенсусу) 
участь у прийнятті рішень; прихований (установлений системою цінностей) контроль замість наявного, заснованого на цифрових показниках; висока культура.

У структурі реального навчального процесу функціонує безліч різноманітних зв'язків і відношень, які зумовлюють його багатоелементність і різнохарактерність, а відтак, - різноманітність форм, методів, моделей, що реалізують різну його ефективність. Тому нагальною $є$ потреба в пошуках таких методичних систем, що можуть бути ефективними в умовах масового навчання та забезпечувати успіх діяльності кожного викладача і студента. 3-поміж таких пошуків- спроба перетворити навчання на своєрідний технологічний процес 3 гарантованими наслідками. Узагальнення досвіду й аналіз літературних джерел свідчать про те, що здебільшого йдеться про управління навчальним процесом за допомогою інноваційних педагогічних технологій, із яких наразі найменш описаною в педагогічній літературі є тренінг.

Тренінг - це сплановані й систематичні зусилля з модифікації чи розвитку знань і вмінь особистості. Він спрямований на набуття знань і навичок, необхідних задля адекватного виконання конкретного завдання. Специфічність тренінгу полягає в тому, що він передбачає здобуття й засвоєння навичок поведінки, фактів, ідей тощо, необхідних для виконання конкретної роботи. Об'єктом тренінгу є скоріше конкретний вид діяльності, ніж людина. Складність упровадження тренінгу в освітню програму полягає в тому, що він має значну відмінність від освіти. Тренінг, як навчання вузько специфічним формам поведінки, припускає відповідний ступінь одноманітності в межах наявних індивідуальних відмінностей. Освіта, навпаки, характеризується заохоченням індивідуальних особливостей студентів; навчання відбувається так, що кожен студент у результаті розробляє свої власні засоби виконання тієї чи іншої діяльності. Метою тренінгу є забезпечити людину знаннями, вміннями, навичками, необхідними для виконання конкретних завдань. Навчання, або освіта, забезпечує людину теоретичною та концептуальною системою, яка стимулює розвиток аналітичного і критичного мислення. Однак ці два процеси перебувають у тісному взаємозв'язку. Здатність людини до набуття знань і вмінь так чи інакше залежить від якості іiі минулого навчання та ступеня іiі освіченості. Крім цього, і організаційний тренінг, і навчання не можуть обійтися без практичного досвіду [1, с. 26].

Задля надання підготовці майбутніх економістів особистісно-діяльнісної спрямованості пропонуємо враховувати принцип рольової перспективи в процесі навчання шляхом реалізації кожним студентом складної та відповідальної ролі в ситуаціях, максимально наближених до реальних, що сприяє формуванню професійної компетентності, індивідуального стилю діяльності й готовності до творчого виконання професійних управлінських функцій. Рольова перспектива сприяє активізації задатків і здібностей студентів, урахуванню їніх індивідуальнопсихологічних особливостей, стилю розумової діяльності, застосуванню студентами особистого та соціального досвіду, формуванню стереотипів поведінки в ситуаціях професійного спілкування, навичок соціально-професійної взаємодії, розвитку творчого мислення та отриманню досвіду щодо аналізу професійних завдань.

Тому досить ефективними для формування готовності майбутніх економістів до інноваційної професійної діяльності вважаємо ділові ігри (рольові, імітаційні, інтелектуальні тощо).

Ділова гра - це імітація робочого процесу, моделювання, спрощене відтворення реальної економічної ситуації. Перед учасниками гри ставляться завдання, аналогічні тим, які вони вирішуватимуть у щоденній професійній діяльності. Ці завдання можуть 
бути найрізноманітнішими, наприклад: виконання плану продажів по кожній групі товарів, виведення нового продукту на ринок, відкриття магазинів у регіонах та інші. При цьому учасники гри за 1-3 години можуть «прожити» і 1 тиждень, і 1 місяць, і 1 рік.

Застосування ділових ігор дозволяє відпрацювати професійні навички учасників. Окрім того, це дає можливість оцінити: рівень володіння цими навичками; особливості розумових процесів (стратегічне, тактичне, аналітичне мислення, уміння прогнозувати ситуацію, уміння ухвалювати рішення тощо.); рівень комунікативних навичок; особистісні якості учасників.

Процедура ділової гри розробляється під конкретну дисципліну - поведінка споживачів, маркетинг інновацій, маркетингові комунікації тощо. Перш за все враховується специфіка дисципліни і практичні навички, які повинен отримати студент у результаті їі вивчення. Виходячи з цілей, проводиться серйозна попередня робота з пошуку інформації про особливості роботи в певній Компанії для того, щоб максимально наблизити ігрові умови до реальності. Після цього розробляється сюжет, визначаються процедури, прописуються ролі, розробляються системи оцінки дій гравців, підрахунку набраних балів, складається тайминг гри. Вся процедура поетапно узгоджується з керівництвом Компанії, а також з викладацьким складом кафедри.

Задля формування навичок командної роботи майбутнім економістам пропонували стратегічну гру «Створення літака», ідею якої ми запозичили в П. Хасіної [2, с. 95]. Студентів поділяли на групи по 4-5 чоловік так, щоб у кожній групі виявився студент 3 ознаками лідерства. Здатних до лідерства студентів визначали завчасно за допомогою анкети. Командам давали завдання створити із запропонованих матеріалів (дерев'яні палички, шматочки пластмаси, папір різних видів, скотч, скрепки, степлер, клей, ножик, нитки, стрічки, пластилін, ножиці тощо) літак, який міг би пролетіти 5 метрів і приземлитись на окресленій території, доставивши туди вантаж (канцелярську гумку тощо).

Матеріали пропонувались усім групам однакові, час обмежувався 2-ма годинами 3 дозволом на перерву за власним бажанням. Робота команд оцінювалась за такими критеріями: якість створеного літака (його здатність летіти, везти вантаж, приземлятись у вказаному місці); швидкість створення літака; естетичний вигляд зразка.

Для викладачів, які спостерігали за перебігом гри, важливо було оцінити ще такі показники членів команд: уміння лідера розподілити ролі та обов'язки; ініціативність кожного у висуненні ідей; здатність кожного прийняти ідею інших членів команди; злагодженість у роботі; відповідальність кожного за кінцевий результат; готовність прийти на допомогу іншому тощо.

Участь майбутніх економістів у таких стратегічних іграх сприяла усвідомленню кожним, що успіх команди залежить від якості роботи кожного ії члена, виробленню почуття командного духу, розвитку навичок командної співпраці.

Кожна ділова гра служить для оцінювання декількох компетенцій, до яких можна віднести, наприклад, такі [3]: аналітичні здібності; стратегічне управління, управління стосунками; управлінські навички лідера; навички роботи в команді; креативність; організаційні здібності; особисті якості і психологічні особливості.

Оцінка вищевикладених компетенцій допомагає студентові виявити свої слабкі й сильні сторони й визначитись 3 напрямом майбутньої професійної діяльності. Тому ділові ігри використовуються не лише як ефективна активна форма практичного навчання студентів, але і як система, що дозволяє визначитися 3 тим, який напрям майбутньої професійної діяльності відповідатиме особливостям студента.

Ділова гра в нашій практиці- це спосіб моделювання різноманітних умов професійної діяльності методом пошуку нових можливостей її виконання. Це - метод пошуку рішень в умовній проблемній ситуації, який застосовується як засіб активного навчання учасників задля вироблення в них навичок прийняття рішень у нестандартних ситуаціях, а також як засіб тестування здібностей. Ділова гра імітує 
різні аспекти економічної діяльності й соціальної взаємодії та є засобом ефективного навчання завдяки тому, що усуває суперечність між абстрактним характером навчального предмета та реальним характером професійної діяльності. Саме цим вона сприяє скороченню часу, відведеного на вивчення теми, й ефективнішому засвоєнню навчального матеріалу процес навчання стає більш творчим і захоплюючим.

Під час застосування ділових ігор навчальний процес максимально наближається до реальної практичної ситуації. Іншими словами, будь-яка ділова гра - це імітаційний метод. Вона стає власне ігровим методом навчання, за якого всі учасники гри виступають у тих чи інших ролях і приймають управлінські рішення відповідно до своєї ролі. Оскільки інтереси учасників гри неоднакові, то їм доводиться іноді приймати рішення в конфліктних ситуаціях. Окрім цього ділова гра $є$ колективним методом навчання. Якщо традиційні методи зорієнтовані, переважно, на індивідуальне навчання студентів, то в ділових іграх, де беруть участь студенти всієї групи, рішення приймаються колективно. Тому вважаємо ділову гру найефективнішою технологією для формування навичок роботи в команді.

Висвітлено шляхи розвитку в майбутніх економістів управлінських якостей i навичок роботи в команді. Визначено, що одним із найефективніших методів у процесі формування професійних умінь $є$ ділова гра, що будується і здійснюється на основі залучення студентів до активності 3 високим рівнем самостійності, а педагогічне керівництво зумовлює розвиток цієї самостійності. Тому ділові ігри розглядаємо як важливий чинник створення відповідного середовища, необхідного задля формування управлінських якостей і вмінь.

\section{Література}

1. Бережна В. Підготовка майбутніх менеджерів до інноваційної професійної діяльності з використанням новітніх засобів навчання / Вікторія Бережна // Науковий вісник Чернівецького університету. - Чернівці : ЧНУ, 2009. - Випуск 468. - С. 21-27. 2. Хасина П. Л. Ролевой состав команды и динамика ее эффективности / П. Л. Хасина // Вопросы психологии: научный журнал. - 2009. - №4. - С.91-98. 3. Тэрбин П. Стратегические игры / Тэрбин Патрик; пер. с англ. - Днепропетровск : Баланс клуб, 2003. - 264 с.

\section{Ростислав Тарасенко}

\section{ОРГАНІЗАЦІЙНО-ПЕДАГОГІЧНІ АСПЕКТИ ФОРМУВАННЯ ІНФОРМАЦЙНОЇ КОМПЕТЕНТНОСТІ МАЙБУТНЬОГО ПЕРЕКЛАДАЧА}

Тарасенко Р. А. Організаційно-педагогічні аспекти формування інформаційної компетентності майбутнього перекладача.

Розглянуто питання інформаційної компетентності майбутніх перекладачів та iii формування на основі базових компетенцій. Запропоновано засоби формування інформаційної компетентності студентів-перекладачів відповідно до концепції створення світового освітнього простору та 3 урахуванням особливостей національної системи освіти.

Ключові слова: інформаційна компетентність, стандарт, студенти, перекладач, інформаційно-комунікаційні технології.

Тарасенко Р. А. Организационно-педагогические аспекты формирования информационной компетентности будущего переводчика.

Рассмотрены вопросы информационной компетентности будущих переводчиков и ее формирование на основе базовых компетенций. Предложены средства формирования информационной компетентности студентов-переводчиков 